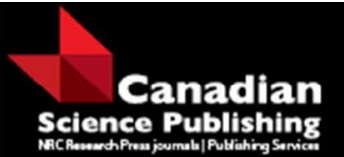

Canadian Journal of Forest Research

Revue canadienne de recherche forestière

\title{
Frequency of sprout-origin trees in pre-European settlement forests of the Southern Appalachian Mountains
}

\begin{tabular}{|r|l|}
\hline Journal: & Canadian Journal of Forest Research \\
\hline Manuscript ID & cjfr-2016-0078.R1 \\
\hline Manuscript Type: & Article \\
\hline Date Submitted by the Author: & $20-$ May-2016 \\
\hline Complete List of Authors: & $\begin{array}{l}\text { Copenheaver, Carolyn; Virginia Polytechnic Institute and State University } \\
\text { Keyser, Tara; USDA Forest Service }\end{array}$ \\
\hline Keyword: & $\begin{array}{l}\text { forest disturbance, oak regeneration, eastern deciduous forest, forest } \\
\text { structure, witness trees }\end{array}$ \\
\hline & \multicolumn{2}{|l}{} \\
\hline
\end{tabular}

SCHOLARONE $^{\text {IM }}$

Manuscripts 
3

Frequency of sprout-origin trees in pre-European settlement forests of the Southern Appalachian Mountains

6

9 C.A. Copenheaver. Department of Forest Resources and Environmental Conservation, Virginia 10 Tech, Blacksburg, VA 24060, USA. Email: ccopenhe@vt.edu

11 T.L. Keyser. USDA Forest Service Southern Research Station, Bent Creek Experimental Forest, 121577 Brevard Road, Asheville, NC 28806, USA. Email: tkeyser@fs.fed.us

13

14 Corresponding Author:

15 Carolyn A. Copenheaver

16 Department of Forest Resources and Environmental Conservation

17232 Cheatham Hall (Mail Code: 0324)

18 Virginia Tech

19 Blacksburg, VA 24060

20 (T): 1-540-231-4031

21 (F): 1-540-231-3330

22 (E): ccopenhe@vt.edu

23 
26 Abstract: We hypothesized that tree form, recorded in historical public land surveys would

27 provide a valuable proxy record of regeneration patterns during early-European settlement of

28 North America's eastern deciduous forest. To test this hypothesis, we tallied stem form from

29 witness trees used in land survey records in the southern Appalachian Mountains from 13

30 counties spanning four physiographic provinces: Piedmont, Blue Ridge, Ridge and Valley, and

31 Cumberland Plateau. A total of 3\% of witness trees used in the land surveys were of sprout

32 origin. American basswood (Tilia americana L.) exhibited the highest proportion of sprout-

33 origin trees at $12 \%$. Other overstory species with a high proportion of sprout-origin trees were

34 hickory (Carya sp.), red maple (Acer rubrum L.), and sycamore (Platanus occidentalis L.), all

35 with $6 \%$ of stems being from sprout-origin. The Blue Ridge had significantly more sprout-origin

36 trees compared to the other three physiographic provinces. Forests in the southern Appalachian

37 Mountains during the pre-European settlement period had a suite of disturbances that controlled

38 their growth and regeneration; however, most of these disturbances did not result in large-scale

39 tree mortality and therefore, sprouts were not an important source of regeneration.

40 Key-words: forest disturbance, oak regeneration, eastern deciduous forest, forest structure 41 


\section{Introduction}

European settlement of North America provided a unique opportunity to quantify how

44 substantial shifts in human land use impacted terrestrial ecosystems. The environmental

45 conditions prior to European settlement serve as baseline conditions with which to compare

46 present-day ecosystems. Differences in species composition, species distribution, forest

47 structure, and disturbance regimes between these two time periods have been attributed to the

48 introduction of intensive agriculture, large-scale timber harvesting, exotic species, loss of native

49 species, and fire exclusion (McEwan et al. 2011). As scientists have reconstructed pre-European

50 settlement environmental conditions to better understand human impacts on the environment,

51 land managers have appropriated these baseline reconstructions and are using them as goals for

52 habitat restoration (Brose et al. 2001). The use of an arbitrary reference period as a restoration

53 baseline has been criticized in some situations (Jachowski et al. 2015). However, in eastern

54 deciduous forests the baseline of European settlement is often applied because the perceived

55 attributes of this period, specifically oak dominance, match forest management goals (Brose 56 2014).

Reconstructions of historical vegetation and disturbance regimes are founded on proxy records. In eastern deciduous forests, the most valuable proxy sources include: paleoecological records preserved in soils and lake sediments; spatially explicit demographic data from trees; fire

60 scars and dendroecological analysis of tree-ring growth patterns; historical forest measurements;

61 and original land survey records (Russell 1997). Often two proxy sources are compared to

62 validate reconstructions. For example, land survey records (Abrams and McCay 1996) and

63 historical forest measurements (Burke 2011) reveal the same influence of topographic position

64 on species distribution. Occasionally different proxy sources yield conflicting representations of 
pre-European settlement baseline conditions, which requires researchers to reconstruct environmental conditions from an amalgamation of multiple proxy sources.

The importance of disturbance in eastern deciduous forests has become a source of discussion because different proxy sources provide conflicting reconstructions of types of disturbance and patterns of forest regeneration common in pre-European settlement times. Annual fire scars and land survey records provide evidence of a fire-based disturbance regime with a modal fire return interval of 7 years and a predominance of sprout-origin, fire-adapted tree species (Shumway et al. 2001; Thomas-Van Gundy and Nowacki 2013; Aldrich et al. 2014). Paleoecological records (Clark and Royal 1996) and dendroecological patterns (Copenheaver et al. 2014) reveal an oak-dominated forest where fire was infrequent at some locations and the forest canopy remained undisturbed for long periods. The differences among proxy reconstructions of disturbance may be attributed to higher levels of regional variation in preEuropean settlement forests (Matlack 2013). In present-day forests, widespread agricultural disturbance, associated with European settlement, has homogenized the forested landscape (Thompson et al. 2013). Thus, perhaps the varied reconstructions of disturbance identified in the various proxy sources accurately reflect a historically heterogeneous forest.

In this study, we examine a commonly used proxy, land surveys, but extract new information on tree form or architecture with the hope of contributing to the on-going discussion about the nature of disturbance and regeneration in the eastern deciduous forest during the period of European settlement. Public and private land surveys allowed the purchase of property by new landowners and were archived as public records. Most land surveys contain parcel descriptions that reference trees blazed by the surveyor to "witness" survey points. Forest historians in the early 1900s realized the ecological value of witness trees because they provided 
a reference point of forest species composition during a period when European land uses had not substantially altered the North American landscape (Sears 1925). Witness tree records, although not originally intended to sample historic forest conditions, remain one of the most valuable quantitative records of the forest condition from the period of European settlement (Liu et al. 2011). In this study, we propose to use the frequency of sprout-origin trees used for witness trees as a representation of importance of disturbance on the pre-European settlement landscape. Trees sprout in response to damage to the main stem (Lamont et al. 2011); therefore, frequency of sprout-origin trees indicates a history of tree damage that can serve as a proxy for frequency of disturbance (Del Tredici 2001).

In the North American eastern deciduous forest, many tree species have the ability to stump sprout after the main stem is damaged by fire, wind, or harvesting. In management of forests for timber production, stump sprouts provide a valuable source of regeneration, especially on infertile sites (Lamson 1976). Their economic importance means we have fairly accurate measurements of stump sprouting rates following timber harvesting. Following clearcutting, $72 \%$ of yellow poplar (Liriodendron tulipifera L.), 90\% of red maple (Acer rubrum L.), and 84\% of chestnut oak (Quercus montana Willd.) stumps produced at least one sprout (Mann 1984). After thinning, stump sprout rates were $91 \%$ for yellow poplar, $95 \%$ for red maple, and $86 \%$ for chestnut oak (Keyser and Zarnoch 2014). Surveys of post-harvest sites report 10 to $53 \%$ of the reproduction is in the form of double- or multiple-sprouts originating from single stem (Wendel and Trimble 1968). In western conifer forests, multiple-stem form occasionally results from germination of several seeds from a wildlife food cache; however, in eastern forests sprout-origin trees are an indication of sprouting following damage to the original parent tree (Linhart and Tomback 1985). 
Sprouting behavior following natural disturbance is less well documented than sprouting

112 following harvesting. Much of what we know about non-harvest-related sprouting comes from

113 experiments where researchers mimicked natural disturbance events to study regeneration

114 patterns. In two studies of artificially created canopy gaps, sprouts accounted for $26-87 \%$ of

115 initial regeneration; however, survivorship of sprouts was not sustained and by the time stems

116 reached $>5 \mathrm{~cm}$ dbh, sprouts only accounted for $11 \%$ of surviving trees (Dietze and Clark 2008;

117 Barker Plotkin et al. 2013). With controlled burning, vigorous sprouting occurred in fire-

118 damaged trees, but repeated controlled burns reduced the vigor and frequency of sprouting,

119 perhaps because of a lack of below-ground carbon reserves (Arthur et al. 2015). One of the only

120 studies that examined historical fire and long term survivorship of sprouts found that black oak

121 (Quercus velutina Lam.) developed multiple-sprouts one to two years after the fire and that

122 multiple sprout-origin stems from a common parent survived to maturity (Dinh et al. 2015).

In post-European settlement, sprout-based regeneration of hardwood trees dominates

124 large areas of the southern Appalachian Mountains because forests regularly experience a suite

125 of interacting disturbances (Dietze and Clark 2008). Dendroecological reconstructions of

126 disturbance have identified disease, drought, fire, hurricanes, ice storms, individual tree gap

127 dynamics, and insect outbreaks as factors that regularly impact tree growth and mortality (Lafon

128 2004; van de Gevel et al. 2012; Butler et al. 2014; Copenheaver et al. 2014). In lands that are not

129 actively managed for timber production, forests have increased in the frequency of hardwood

130 species capable of vigorous sprouting following periods of forest clearance, agriculture, and land

131 abandonment (Flatley and Copenheaver 2015). In managed forests, sprouts from cut stumps are

132 often relied upon as important source of regeneration (Keyser and Loftis 2015). In present-day

133 eastern deciduous forest of the southern Appalachian Mountains, sprouts are the primary form of 
134 regeneration; however, we do not know whether this represents a shift in regeneration patterns 135 associated with European settlement.

Therefore, the objectives of this project were to: (1) evaluate the potential of using tree

137 form in witness tree records to quantify disturbance in the southern Appalachian Mountain

138 region during early European settlement; (2) identify species differences in sprout-origin trees

139 from land survey records; and (3) compare the frequency of sprout-origin trees across four

140 physiographic provinces (Piedmont, Blue Ridge, Ridge and Valley, and Cumberland Plateau) to

141 identify potential landscape differences in historical disturbance regimes.

143 Methods

144 Study area and historical dataset

We selected 13 counties spanning four physiographic provinces that are centered on the southern Appalachian Mountains: Piedmont, Blue Ridge, Ridge and Valley, and Cumberland

147 Plateau (Table 1, Figure 1). The physiographic provinces are a part of the eastern deciduous

148 forest, but there are slight variations in species dominance caused by topography and associated

149 edaphoclimatic gradients. Forests of the rolling Piedmont physiographic province are uniformly

150 dominated by white oak (Quercus alba L.) with other important species being black oak,

151 chestnut oak, mockernut hickory (Carya tomentosa (Lam.) Nutt.), pignut hickory (Carya glabra

152 (Mill.) Sweet), red maple, scarlet oak (Quercus coccinea Muenchh), shagbark hickory (Carya

153 ovata (Mill. K. Koch), sycamore (Platanus occidentalis L.), white ash (Fraxinus 7mericana L.),

154 and yellow poplar (Gemborys 1974; Farrell and Ware 1991). The forests of the more

155 mountainous Blue Ridge physiographic province are dominated by red oak (Quercus rubra L.), 
156 sugar maple (Acer saccharum Marshall.), sweet birch (Betula lenta L.), and white ash (Abrams

157 et al. 1997; van de Gevel et al. 2012). Forest composition in the Ridge and Valley is dominated

158 by chestnut oak, red maple, red oak, scarlet oak, and white oak (Adams and Stephenson 1983).

159 The Cumberland Plateau's forests are dominated by beech (Fagus grandifolia Ehrh.), black oak, 160 chestnut oak, mockernut hickory, red maple, red oak, scarlet oak, shagbark hickory, shortleaf 161 pine (Pinus echinata Mill.), sourwood (Oxydendrum arboreum (L.) DC), sugar maple, and white 162 oak (Hart and Grissino-Mayer 2008; Hart et al. 2012).

Each county government archives land survey books that date from the establishment of the county. We transcribed all of the witness trees from land survey descriptions included in the 165 oldest deed book from each county (the one exception was Buncombe County, North Carolina, where we transcribed the first two books because the first book contained relatively few land 167 surveys). The land descriptions contained distances, directions, and references to witness trees used to identify the location of survey points. For example, a 31-ha land parcel sold in Giles County, Virginia, on September 29, 1806, was described as follows (n.b., bearings are 170 abbreviated as N47W for north 47 degrees west): beginning at a black oak corner to Thomas Shannon's land and runneth thence N47W 34 poles to a lynn and two chestnuts N82W 88 poles to a chestnut and 2 dogwoods S50W 20 poles thence N70W 30 poles to two chestnuts growing from one root S9W 26 poles to two chestnuts S27E 122 poles crossing Sugar Run to a chestnut and cucumber in a hollow S77E 56 poles to a chestnut and cucumber in a hollow S77E 56 poles to a chestnut oak on a north hill side N10E 48 poles to a lynn and white walnut on a line of his own lands and running N71W 80 poles to 

two poplars and running thence N67E 123 poles to the beginning (Giles County Deedbook A, Page 50)

For each county, all witness trees were tallied, by species, into four categories: single-stem tree, sprout-origin tree, sapling, and dead. When only the species was identified, the tree was classified as a single-stem tree. Sprout-origin trees were identified in different ways depending upon the surveyor. We classified a tree as being of sprout-origin if it was described as: bunch, bush, cluster, double, forked, grub, three forked, three pronged, triple, twin, shrub, two from one root, three from one root, four from one root, or a bunch growing from one root. It was not unusual for a survey point to include more than one witness tree; e.g., the two yellow poplars mentioned in the above example. However, these were not classified as sprout-origin trees because the surveyors differentiated between two trees witnessing the same survey point and two stems that shared a common root. This is evidenced in a land description from Grayson County, Virginia's Deedbook 1, Page 500, which identifies a survey point as witnessed by "two white oaks, one of them double." A tree was classified as a sapling if it was identified as small or a sapling. Dead trees were described by surveyors as: broke, dead, dry, fallen, fallen down, lying down, stumps, or thunderstruck.

The handwritten deeds recorded in county courthouses provided substantially more detailed information about individual witness trees than the more commonly employed connected drafts or township contiguous warrantee maps (Black and Abrams 2001; Thomas-Van Gundy and Strager 2012). The connected drafts only report the tree species, but deed records were intended for land surveyors to be able to relocate specific witness trees. Therefore, they commonly included detailed descriptions of individual trees, e.g "a black oak with a flint stone growing in its base" (Iredell County, North Carolina's Deedbook A, Page 492) and "a white oak 
201

202

203

204

205

206

207

208

209

210

211

212

213

214

215

216

217

218

219

220

221

222

223

marked T with a tomahawk" (Kanawha County, West Virginia's Deedbook A, Page 217).

However, the metes-and-bounds witness trees lack information included with "bearing trees" recorded in the rectangular land survey system and some private land surveys that would have allowed quantification of surveyor biases in selection of trees. Bearing trees from the rectangular survey system have distance and bearing from the survey point and often included a diameter measurement of the tree (White 1991). This additional information is used to identify surveyor biases (Kronenfeld and Wang 2007). Favored species or tree sizes will have a longer average distance because surveyors traveled further to select those individuals. Because metesand-bounds witness trees lack this additional information, it is not possible to identify treespecific biases from the survey data. Thus, it impossible to ascertain whether surveyors would have favored single-stem trees, sprout-origin trees, saplings, or dead trees. Another resource commonly employed to identify potential biases in tree selection by land surveyors are government manuals that outline the standards and methods for surveying public and private lands. The survey manual that would have been current with the collection of this data was the Land Ordinance of 1785, which provided surveyors with explicit instructions about how to establish the rectangular survey system in new territory (Cazier 1978). However, our study site in the southern Appalachian Mountains was already settled. Therefore, surveyors continued to use the less formalized colonial-era metes-and-bounds survey method. For the land surveys used in this study, it is not possible to identify whether surveyors were biased for or against the use of multiple-stemmed trees as witness trees from survey instructions. The inability to quantify a potential bias in selection of witness trees based on tree form, does not negate the value of examining patterns of tree form from witness tree records, but it does suggest that we should view the results with the understanding that biases may have existed. 


\section{Data analysis}

We used chi-squared contingency table analysis to evaluate whether tree species varied in

227 the distribution of tree type (single stem, sprout origin, or sapling) used in the historical land

228 surveys. One of the assumptions of the chi-squared contingency table test is that fewer than $20 \%$

229 of the expected values should be less than five individuals and none should be less than one

230 individual (Devore and Farnum 2005). Therefore, we discarded all dead trees and were unable

231 to include minor tree species in this analysis because they did not have a sufficiently large

232 sample size to meet this assumption. Thus, this analysis was completed with 23 of the most

233 frequently occurring tree species used by the land surveyors.

We used chi-squared contingency table analysis to evaluate whether the distribution of

235 witness tree type (single stem, sprout origin, sapling, or dead) used in historical land surveys

236 varied across the four physiographic provinces: Piedmont, Blue Ridge, Ridge and Valley, and

237 Cumberland Plateau. The witness tree data served as the observed values for this test and the test 238 was evaluated at an $\alpha$-level of 0.05 . The sample size was sufficiently large that we met all of the 239 requirements for this test.

\section{Results}

\section{Species-level analysis}

243 A total of 58 species were identified by land surveyors and used as witness trees in the 13

244 counties examined in this study. Witness trees varied significantly $\left(\chi^{2}=1062, \mathrm{P}<0.00001\right)$, by 
245 species, in their distribution across stem form classes. Basswood (Tilia americana L.) had the 246 highest proportion (12\%) of witness trees of sprout origin (Table 2). There were three trees that 247 had a modest proportion of sprout origin stems: hickory (6\%), red maple $(6 \%)$, and sycamore $248(6 \%)$. White oak and hickory had the highest proportion of saplings (both 11\%) used as witness trees. Black oak and locust (Robinia pseudoacacia L.) had a moderate (9\%) proportion of saplings. Note that rare species, dead trees, and species that never had sprout-origin trees in the witness tree record were not included in this analysis. One minor species that had a high proportion of sprout-origin tree was red bud (Cercis canadensis L.) with 15\%. Dead trees were seldom used as witness trees; however, they were present in some land survey records. Butternut (Juglans cinerea L.) had the highest proportion of witness trees that were dead snags or stumps $(2 \%)$. There were 15 species used as witness trees with no stems described as being of sprout origin. However, it should be noted that most of these species were rarely selected as witness

257 trees. Therefore, the lack of sprout-origin trees is more likely an indication of inadequate 258 representation of a species rather than inability to sprout following damage. Note the small 259 sample sizes for those species that lacked individuals of sprout origin: boxelder $(\mathrm{n}=19$, Acer 260 negundo L.), crab apple $(\mathrm{n}=8$, Pyrus coronaria $\mathrm{L})$, eastern red cedar $(\mathrm{n}=16$, Juniperus 261 virginiana L.), hackberry ( $\mathrm{n}=30$, Celtis occidentalis L.), hawthorne $(\mathrm{n}=3$, Crataegus spp.), 262 holly ( $\mathrm{n}=24$, Ilex opaca Aiton.), ironwood $(\mathrm{n}=44$, Carpinus caroliniana Walter.), mountain 263 ash $(\mathrm{n}=9$, Sorbus americana Marshall.), mountain laurel ( $\mathrm{n}=3$, Kalmia latifolia L.), pawpaw (n $264=18$, Asimina triloba (L.) Dunal.), pin oak ( $\mathrm{n}=7$, Quercus palustris Muenchh.), swamp white 265 oak ( $\mathrm{n}=6$, Quercus bicolor Willd.), sweet gum $(\mathrm{n}=52$, Liquidambar styraciflua $\mathrm{L}$.$) , water oak$ 266 (n = 58, Quercus nigra L.), and wahoo (n=3, Euonymus atropurpureus Jacq.). 


\section{Landscape-level analysis}

269 The ratio of stem form used for witness trees was not the same across all four physiographic

270 provinces $\left(\chi^{2}=814, \mathrm{P}<0.00001\right)$. The Blue Ridge had the highest proportion of witness trees

271 that were of sprout origin (3.6\%) and the Piedmont had the lowest at $1.4 \%$ (Table 3). The higher

272 proportion of sprout-origin trees does not appear to be attributed to a transition in species

273 because common species that grew in all four physiographic provinces showed a general pattern

274 of a higher proportion of sprout-origin stem form in the witness trees from the Blue Ridge (Table

275 4). The Ridge and Valley had the highest proportion of witness trees that were saplings (9.8\%)

276 and this was closely followed by the Blue Ridge with 9.7\% (Table 3). The lowest percentage

277 was found in the Cumberland Plateau, where only $2.3 \%$ of the witness trees were saplings. All

278 four physiographic provinces had a small proportion of dead trees that were used to witness a

279 survey point and these percentages ranged from $0.2 \%$ in the Cumberland Plateau to $0.4 \%$ in the

280 Blue Ridge.

\section{Discussion}

Witness tree records from metes-and-bounds surveys have always been more challenging to use as a proxy record of pre-European settlement forest conditions compared to bearing tree

285 records from rectangular public land surveys. Cogbill et al. (2002) described witness tree data

286 from the northeastern United States as being "unregulated and unstandardized...obscure and

287 found in widely scattered repositories." These challenges explain why most northeastern

288 researchers use secondary sources, known as connected drafts or township contiguous warrantee 289 maps, rather than the original handwritten deeds (Black and Abrams 2001; Thomas-Van Gundy 
290

291

292

293

294

295

296

297

298

299

300

301

302

303

304

305

306

307

308

309

310

311

312

and Strager 2012). However, in the southeastern United States so many courthouse records were destroyed during the Civil War that it is impossible to reconstruct a connected draft of original land surveys because of the extensive spatial gaps in the data. In Virginia, 45 counties experienced catastrophic or considerable loss of courthouse records, e.g., in Caroline County "deed books prior to $1836 \ldots$ were stolen, mutilated, and/or destroyed by Union troops who ransacked the courthouse in May 1864" (Anonymous 2010). Despite the limitations and challenges of using metes-and-bounds witness tree records in the southeastern United States, the information uncovered in this study reveals unexpected shifts in patterns of forest regeneration that we would not have been able to discover without the use of historical metes-and-bounds survey records.

Sprout-origin trees represent only $3 \%$ of the witness trees used in land survey records from the period of early European settlement in the southern Appalachian Mountains. This indicates that most trees did not depend upon sprouting for regeneration. We recognize that the proportion of sprout-origin trees was likely higher than $3 \%$, because not all sprouts survive to maturity. However, survival of double or triple stems to maturity is the norm for eastern deciduous forests. Trees initially produce multiple sprouts from a cut or damaged stump and although there is a high rate of mortality among this initial cohort of sprouts, more than one sprout typically survives to maturity. Red oak has the highest survivorship of sprouts with mature, sprout-origin red oak averaging four stems per stump (Johnson 1975). Sprout-origin black oak, chestnut oak, and white oak are more likely to be double-stemmed rather than multiple-stemmed (McIntyre 1936; McQuilkin 1975; Gould et al. 2007). The frequent survival of double or triple stems into maturity has led silviculturists from this region to recommend thinning sprouts to a single stem to improve stand growth rates (Lamson 1976). Sprout 
313 survivorship studies validate interpreting witness tree stem form as an indication of sprout origin

314 (Keyser and Zarnoch 2014). However, this leaves the important question of why sprout-origin

315 trees were less common in pre-European settlement forests. In present-day, harvest-origin

316 forests, sprout-origin trees comprise $75 \%$ of the individuals and $50 \%$ of the basal area (Ebinger

317 1973). However, in pre-European settlement forests, only $2 \%$ of oaks recorded as witness trees

318 had double or multiple stems meaning the vast majority of oak trees were of seedling rather than

319 sprout origin. Given the inverse relationship between tree diameter and probability of stump

320 sprouting (Keyser and Loftis 2015), it may be possible that pre-European settlement forests had a

321 greater proportion of larger diameter trees and this stand structure reduced the likelihood of

322 regeneration from sprouts after damage to the original stem. Additionally, natural disturbance

323 events, such as wind storms, resulted in fewer trees sprouting after stem damage (Peterson 2000)

324 than occurred when trees were felled during harvesting. Unfortunately, metes-and-bounds

325 witness trees do not include stem diameter and therefore, it is not possible to reconstruct

326 diameter distributions of historical stands.

Fewer sprout-origin trees in pre-European settlement forests could result from either

328 more trees regenerating from seed (resulting in a higher frequency of single stem trees) or a

329 lower survivorship of sprouts (resulting in a higher frequency of single stem trees). In Chinese

330 forests, multi-stemmed snakebark maple (Acer tegmentosum) decrease in frequency in stands

331 with higher basal area because of self-thinning of sprouts induced by competition for light (Ye et

332 al. 2014). Silvicultural studies on oak stump sprouts have reported a decline in survivorship with

333 reduced light availability in the understory (Dey et al. 2008). Disturbances caused by allogenic

334 events that create high-light conditions in the understory, e.g. hurricanes, insect outbreaks, ice

335 storms, timber harvesting, and sustained periods of drought (Butler et al. 2014), may be more 
336

337

338

common in present-day forests and may have resulted in both an increase in the frequency of sprouting and a higher survival of sprouts because of high-light conditions caused by extensive canopy damage.

We had hoped that examining stem form in witness tree records would reveal specieslevel differences in regeneration patterns under environmental conditions that pre-date European style land uses. Basswood has long been identified as a species that has benefitted from the introduced of European-style forest harvesting because of its unequaled ability to sprout from cut stumps (Scholz 1958) and it has been theorized that with regular disturbance basswood "seems to be capable of perpetuating itself indefinitely by basal sprouts" (Daubenmire 1936). The witness tree records (Table 2) show that the ability to sprout also benefitted basswood in pre-European settlement forests and based on landscape differences in stem form (Table 4) it is likely that the disturbance that benefitted basswood during this era was fire. Basswood had its highest proportion of sprout-origin trees $(20 \%$, Table 4$)$ in the Blue Ridge physiographic province and other proxy records show that because of longer periods of dry weather, fire was more frequent in the Blue Ridge than in the Ridge and Valley or the Cumberland Plateau (Aldrich et al. 2014). Thus, basswood has retained a similar pattern of regenerating largely through sprouts; however, the cause of disturbance has shifted from fire during pre-European settlement conditions to harvesting in present-day forests.

Sprout-origin stem form is not always an indication of disturbance, it can also reflect a species' silvics and/or abiotic growing conditions. In temperate forests in China, $27 \%$ of snakebark maple trees have multiple stems, but only $3 \%$ of painted maple (Acer mono) trees have multiple stems and individuals growing at high elevations are more likely to have multiple stems than those growing at lower elevations (Ye et al. 2014). In this study sycamore was a 
359 species with a relatively high proportion (6\%) of sprout-origin witness trees (Table 2). In open-

360 grown conditions, sycamore takes on the spreading, multi-stemmed shape (Wells and

361 Schmidtling 1990) described by the surveyors. A vast majority of the surveys that used

362 sycamore as witness trees included a description of a riparian location that would have favored

363 the spreading crown associated in this species under open growing conditions, e.g., "crossing a

364 part of the river to a sycamore near the upper end of an island" (Giles County, Virginia Deed

365 Book A, Page 33); "to three sycamores on the bank at the mouth of the creek" (Giles County,

366 Virginia Deed Book A, Page 55); and "at a double sycamore on the bank of the river" (Giles

367 County, Virginia Deed Book A, Page 120). Therefore, interpretation of stem form in the witness

368 tree record must include the possibility that the stem form may be a result of the silvics of the

369 species and the growing condition of the tree.

The introduction of extensive harvesting to the forests of the southern Appalachian

371 Mountains has caused a shift in regeneration patterns from seedling germination and release of

372 understory saplings in small canopy gaps to large-scale disturbances that favor sprouting and

373 rapid revegetation (Shure et al. 2006). Studies from other forest types that have experienced a

374 similar increase in the frequency of multi-stemmed trees, have noted that these individuals

375 occupy a larger proportion of the canopy and therefore, stem form directly impacts canopy

376 structure and indirectly impacts photosynthetic and growth rates of forests (Taylor et al. 2016).

377 The witness tree records provide a historical baseline to document a decrease in the importance

378 of seed germination as the primary source of tree establishment in pre-European settlement

379 forests of the southern Appalachian Mountains. 


\section{Acknowledgements}

382 The authors acknowledge K. Hollandsworth who traveled with the authors to several courthouses

383 and assisted with hand transcription of the early land survey records in courthouses that

384 prohibited electronic equipment. Thanks also to K. Frick for assistance with creating the study

385 area map. Partial funding for this project was provided by a McIntire-Stennis Project awarded to

386 C. Copenheaver.

\section{References}

Abrams, M.D., and McCay, D.M. 1996. Vegetation-site relationships of witness trees (17801856) in the presettlement forests of eastern West Virginia. Can. J. For. Res. 26(2): 217224.

Abrams, M.D., Orwig, D.A., and Dockry, M.J. 1997. Dendroecology and successional status of two contrasting old-growth oak forests in the Blue Ridge Mountains, USA. Can. J. For. Res. 27(7): 994-1002.

Adams, H.S., and Stephenson, S.L. 1983. A description of the vegetation on the south slopes of Peters Mountain, southwestern Virginia. B. Torrey Bot. Club 110(1): 18-22.

Aldrich, S.R., Lafon, C.W., Grissino-Mayer, H., and DeWeese, G.G. 2014. Fire history and it relations with land use and climate over three centuries in the central Appalachian Mountains, USA. J. Biogeogr. 41(11): 2093-2104.

Anonymous. 2010. Lost records localities: counties and cities with missing records. Library of Virginia Research Notes Number 30. 
Arthur, M.A., Blankenship, B.A., Schörgendorfer, A., Loftis, D.L., and Alexander, H.D. 2015. Changes in stand structure and tree vigor with repeated prescribed fire in an Appalachian hardwood forest. Forest Ecol. Manag. 340: 46-61.

Barker Plotkin, A., Foster, D., Carlson, J., and Magill, A. 2013. Survivors, not invaders, control forest development following simulated hurricane. Ecology 94(2): 414-423.

Black, B.A., and Abrams, M.D. 2001. Analysis of temporal variation and species-site relationships of witness tree data in southeastern Pennsylvania. Can. J. For. Res. 31(3): 419-429.

Brose, P., Schuler, T., van Lear, D., and Berst, J. 2001. Bringing fire back - the changing regimes of the Appalachian mixed-oak forests. J. Forest. 99(11): 30-35.

Brose, P.H. 2014. Development of prescribed fire as a silvicultural tool for the upland oak forests of the eastern United States. J. Forest. 112(5): 525-533.

Burke, K.L. 2011. The effects of logging and disease on American chestnut. Forest Ecol. Manag. 261(6): 1027-1033.

Butler, S.M., White, A.S., Elliott, K.J., and Seymour, R.S. 2014. Disturbance history and stand dynamics in secondary and old-growth forests of the southern Appalachian Mountains, USA. J. Torrey Bot. Soc. 141(3): 189-204.

Cazier, L. 1978. Surveys and surveyors of the public domain 1785-1975. USDI, Bureau of Land Management.

Clark, J.S., and Royal, P.D. 1996. Local and regional sediment charcoal evidence for fire regimes in presettlement northeastern North America. J. Ecol. 84(3): 365-382. 
Cogbill, C., Burk, J., and Motzkin, G. 2002. The forests of presettlement New England, USA: Spatial and compositional patterns based on town proprietor surveys. J. Biogeogr. 29(1011): $1279-1304$.

Copenheaver, C.A., Seiler, J.R., Peterson, J.A., Evans, A.M., McVay, J.L., and White, J.H. 2014. Stadium Woods: A dendroecological analysis of an old-growth forest fragment on a university campus. Dendrochronologia 32(1): 62-70.

Daubenmire, R.F. 1936. The "Big Woods" of Minnesota: its structure, and relation to climate, fire, and soils. Ecol. Monogr. 6(2): 235-267.

Del Tredici, P. 2001. Sprouting in temperate trees: A morphological and ecological review. The Botanical Review 67(2): 121-140.

Devore, J., and Farnum, N. 2005. Applied Statistics for Engineers and Scientists. Thomson Brooks/Cole, Belmont, CA. pp. 605.

Dey, D.C., Jensen, R.G., and Wallendorf, M.J. 2008. Single-tree harvesting reduces survival and growth of oak stump sprouts in the Missouri Ozark Highlands. In 16th Central Hardwood Forest Conference, West Lafayette, IN, April 8-9, 2008. Edited by D. F. Jacobs and C. H. Michler. USDA Forest Service Northern Research Station, General Technical Report NRS-P-24, 26-37.

Dietze, M.C., and Clark, J.S. 2008. Changing the gap dynamics paradigm: Vegetative regeneration control on forest response to disturbance. Ecol. Monogr. 78(3): 331-347.

Dinh, T., Hewitt, N., and Drezner, T.D. 2015. Fire history reconstruction in the black oak (Quercus velutina) savanna of High Park, Toronto. Nat. Area J. 35(3): 468-475. Ebinger, J.E. 1973. Coppice forest in east-central Illinois. Castanea 38(2): 152-163. 
Farrell, J.D., and Ware, S. 1991. Edaphic factors and forest vegetation in the Piedmont of Virginia. B. Torrey Bot. Club 118(2): 161-169.

Flatley, W.T., and Copenheaver, C.A. 2015. Two centuries of vegetation change in an agricultural watershed in southwestern Virginia, USA. J. Torrey Bot. Soc. 142(2): 113126.

Gemborys, S.R. 1974. The structure of hardwood forest ecosystems of Price Edward County, Virginia. Ecology 55(3): 614-621.

Gould, P.J., S., F., and Steiner, K.C. 2007. Modeling sprout-origin oak regeneration in the central Appalachians. Can. J. For. Res. 37(1): 170-177.

Hart, J.L., Clark, S.L., Torreano, S.J., and Buchanan, M.L. 2012. Composition, structure, and dendroecology of an old-growth Quercus forest on the tablelands of the Cumberland Plateau, USA. Forest Ecol. Manag. 266: 11-24.

Hart, J.L., and Grissino-Mayer, H. 2008. Vegetation patterns and dendroecology of a mixed hardwood forest on the Cumberland Plateau: implications for stand development. Forest Ecol. Manag. 255(5-6): 1960-1975.

Jachowski, D.S., Kesler, D.C., Steen, D.A., and Walters, J.R. 2015. Redefining baselines in endangered species recovery. The Journal of Wildlife Management 79(1): 3-9.

Johnson, P.S. 1975. Growth and structural development of red oak sprout clumps. For. Sci. 21(4): 413-418.

Keyser, T.L., and Loftis, D.L. 2015. Stump sprouting of 19 upland hardwood species 1 year following initiation of a shelterwood with reserves silvicultural system in the southern Appalachian Mountains, USA. New Forest. 46(3): 449-464. 
Keyser, T.L., and Zarnoch, S.J. 2014. Stump sprout dynamics in response to reductions in stand density for nine upland hardwood species in the southern Appalachian Mountains. Forest Ecol. Manag. 319: 29-35.

Kronenfeld, B.J., and Wang, Y.C. 2007. Accounting for surveyor inconsistency and bias in estimation of tree density from presettlement land survey records. Can. J. For. Res. 37(11): 2365-2379.

Lafon, C.W. 2004. Stand dynamics of a yellow-poplar (Liriodendron tulipifera L.) forest in the Appalachian Mountains, Virginia, USA. Dendrochronologia 22(1): 43-52.

Lamont, B.B., Enright, N.J., and He, T. 2011. Fitness evolution of resprouters in relation to fire. Plant Ecol. 212(12): 1945-1957.

Lamson, N.I. 1976. Appalachian hardwood stump sprouts are potential sawlog crop trees. USDA Forest Service, Northeastern Forest Experiment Station. Research Note NE-229.

Linhart, Y.B., and Tomback, D.F. 1985. Seed dispersal by nutcrackers causes multi-truck growth form in pines. Oecologia 67(1): 107-110.

Liu, F., Mladenoff, D.J., Keuler, N.S., and Moore, L.S. 2011. Broadscale variablity in tree data of the historical Public Land Survey and its consequences for ecological studies. Ecol. Monogr. 81(2): 259-275.

Mann, L.K. 1984. First-year regeneration in upland hardwoods after two levels of residue removal. Can. J. For. Res. 14(3): 336-342.

Matlack, G.R. 2013. Reassessment of the use of fire as a management tool in deciduous forests of eastern North America. Conserv. Biol. 27(5): 916-926. 
McEwan, R.W., Dyer, J.M., and Pederson, N. 2011. Multiple interacting ecosystem drivers: toward an encompassing hypothesis of oak forest dynamics across eastern North America. Ecography 34(2): 244-256.

McIntyre, A.C. 1936. Sprout groups and their relation to the oak forests of Pennsylvania. J. Forest. 34(12): 1054-1058.

McQuilkin, R.A. 1975. Growth of four types of white oak reproduction after clearcutting in the Missouri Ozarks. USDA Forest Service North Central Experiment Station, St. Paul, MN. Research Paper NC-116.

Peterson, C.J. 2000. Damage and recovery of tree species after two different tornadoes in the same old-growth forest: a comparison of infrequent wind disturbances. Forest Ecol. Manag. 135: 237-252.

Russell, E.W.B. 1997. People and the Land Through Time: Linking Ecology and History. Yale University Press, New Haven, CT. pp. 306.

Scholz, H.F. 1958. Silvical characteristics of American basswoods. USDA Forest Service, Lake States Forest Experiment Station Paper No. 62.

Sears, P.B. 1925. The natural vegetation of Ohio. The Ohio Journal of Science 25(3): 139-149. Shumway, D.L., Abrams, M.D., and Ruffner, C.M. 2001. A 400-year history of fire and oak recruitment in an old-growth oak forest in western Maryland. Can. J. For. Res. 31(8): 1437-1443.

Shure, D.J., Phillips, D.L., and Bostick, P.E. 2006. Gap size and succession in cutover southern Appalachian forests: an 18 year study of vegetation dynamics. Plant Ecol. 185(2): 299318. 
Taylor, J.E., Ellis, M.V., Rayner, L., and Ross, K.A. 2016. Variability in allometric relationships for temperate woodland Eucalyptus trees. Forest Ecol. Manag. 360: 122-132.

Thomas-Van Gundy, M.A., and Nowacki, G.J. 2013. The use of witness trees as pyro-indicators for mapping past fire conditions. Forest Ecol. Manag. 304: 333-344.

Thomas-Van Gundy, M.A., and Strager, M.P. 2012. European settlement-era vegetation of the Monongahela National Forest, West Virginia. USDA Forest Service Northern Research Station, General Technical Report NRS-101.

Thompson, J.R., Carpenter, D.N., Cogbill, C.V., and Foster, D.R. 2013. Four centuries of change in northeastern United States forests. PLOS One 8(9): 1-15.

van de Gevel, S., Hart, J.L., Spond, M.D., White, P.B., Sutton, M.N., and Grissino-Mayer, H. 2012. American chestnut (Castanea dentata) to northern red oak (Quercus rubra): forest dynamics of an old-growth forest in the Blue Ridge Mountains, USA. Botany 90(12): 1263-1276.

Wells, O.O., and Schmidtling, R.C. 1990. Sycamore. Silvics of North America. USDA Forest Service, Agricultural Handbook 654.

Wendel, G.W., and Trimble, G.R. 1968. Early reproduction after seed-tree harvest cuttings in Appalachian hardwoods. USDA Forest Service. Research Paper NE-99.

White, C.A. 1991. A history of the rectangular survey system. U.S. Government Printing Office. Ye, J., Hao, Z., Wang, X., Bai, X., Xing, D., and Yuan, Z. 2014. Local-scale drivers of multistemmed tree formation in Acer, in a temperate forest of Northeast China. Chinese Science Bulletin 59(3): 320-325. 
Table 1. Counties from which witness trees were collected from land survey records. Physiographic provinces are listed from east to west and within physiographic provinces; counties are listed from north to south.

\begin{tabular}{|c|c|c|c|c|c|c|}
\hline $\begin{array}{l}\text { Physiographic } \\
\text { Province }\end{array}$ & State & County & County seat & Location of county seat & $\begin{array}{l}\text { Time period of } \\
\text { land records }\end{array}$ & $\begin{array}{c}\text { Total number of } \\
\text { witness trees }\end{array}$ \\
\hline \multirow[t]{4}{*}{ Piedmont } & Virginia & Orange & Orange & $38.2458^{\circ} \mathrm{N}, 78.1097^{\circ} \mathrm{W}$ & 1734 to 1737 & 1258 \\
\hline & Virginia & Patrick & Stuart & $36.6403^{\circ} \mathrm{N}, 80.2739^{\circ} \mathrm{W}$ & 1790 to 1800 & 3454 \\
\hline & $\begin{array}{l}\text { North } \\
\text { Carolina }\end{array}$ & Stokes & Danbury & $36.4094^{\circ} \mathrm{N}, 80.2089^{\circ} \mathrm{W}$ & 1788 to 1793 & 1430 \\
\hline & $\begin{array}{l}\text { North } \\
\text { Carolina }\end{array}$ & Iredell & Statesville & $35.7867^{\circ} \mathrm{N}, 80.8786^{\circ} \mathrm{W}$ & 1788 to 1793 & 1710 \\
\hline \multirow[t]{3}{*}{ Blue Ridge } & Virginia & Grayson & Independence & $36.6228^{\circ} \mathrm{N}, 81.1517^{\circ} \mathrm{W}$ & 1793 to 1802 & 2995 \\
\hline & $\begin{array}{l}\text { North } \\
\text { Carolina }\end{array}$ & Ashe & Jefferson & $36.4200^{\circ} \mathrm{N}, 81.4689^{\circ} \mathrm{W}$ & 1799 to 1802 & 2059 \\
\hline & $\begin{array}{l}\text { North } \\
\text { Carolina }\end{array}$ & Buncombe & Asheville & $35.5800^{\circ} \mathrm{N}, 82.5558^{\circ} \mathrm{W}$ & 1805 to 1808 & 1985 \\
\hline \multirow{3}{*}{$\begin{array}{l}\text { Ridge and } \\
\text { Valley }\end{array}$} & Virginia & Botetourt & Fincastle & $37.4994^{\circ} \mathrm{N}, 79.8767^{\circ} \mathrm{W}$ & 1770 to 1773 & 3290 \\
\hline & Virginia & Giles & Pearisburg & $37.3292^{\circ} \mathrm{N}, 80.7325^{\circ} \mathrm{W}$ & 1806 to 1818 & 5612 \\
\hline & Tennessee & Hawkins & Rogersville & $36.4167^{\circ} \mathrm{N}, 83.0000^{\circ} \mathrm{W}$ & 1788 to 1801 & 2029 \\
\hline \multirow[t]{3}{*}{$\begin{array}{l}\text { Cumberland } \\
\text { Plateau }\end{array}$} & $\begin{array}{l}\text { West } \\
\text { Virginia }\end{array}$ & Kanawha & Charleston & $38.3472^{\circ} \mathrm{N}, 81.6333^{\circ} \mathrm{W}$ & 1790 to 1801 & 2166 \\
\hline & Kentucky & Pike & Pikeville & $37.4772^{\circ} \mathrm{N}, 82.5300^{\circ} \mathrm{W}$ & 1822 to 1833 & 3358 \\
\hline & Tennessee & Marion & Jasper & $35.0750^{\circ} \mathrm{N}, 85.6281^{\circ} \mathrm{W}$ & 1819 to 1830 & 1457 \\
\hline
\end{tabular}


1 Table 2. Common witness trees reported in land surveys from 1734 to 1830 in 13 counties in the

2 Southern Appalachian Mountains. Species did not have the same ratio of individuals in each

3 stem form (single stem trees, sprout-origin trees, or saplings), indicating some species were more

4 likely to have reproduced from sprouts than others. Note: witness trees classified as dead are not

5 shown in this table.

\begin{tabular}{|c|c|c|c|c|}
\hline Common name & Scientific name & $\begin{array}{c}\text { Single-stem } \\
\text { trees }\end{array}$ & $\begin{array}{c}\text { Sprout- } \\
\text { origin trees }\end{array}$ & Saplings \\
\hline Ash & Fraxinus L. & $511(90 \%)$ & $14(3 \%)$ & $39(7 \%)$ \\
\hline Basswood & Tilia americana L. & $349(87 \%)$ & $48(12 \%)$ & $4(1 \%)$ \\
\hline Beech & Fagus grandifolia Ehrh. & $1976(96 \%)$ & $23(1 \%)$ & $57(3 \%)$ \\
\hline Black gum & Nyssa sylvatica Marshall. & $557(91 \%)$ & $4(1 \%)$ & $45(7 \%)$ \\
\hline Black oak & Quercus velutina Lam. & $2074(89 \%)$ & $36(2 \%)$ & $204(9 \%)$ \\
\hline Black walnut & Juglans nigra L. & $400(93 \%)$ & $11(3 \%)$ & $17(4 \%)$ \\
\hline Buckeye & Aesculus flava Aiton. & $319(94 \%)$ & $8(2 \%)$ & $9(3 \%)$ \\
\hline \multirow[t]{2}{*}{ Chestnut } & Castanea dentata (Marshall) & $1996(95 \%)$ & $80(4 \%)$ & $24(1 \%)$ \\
\hline & Borkh & & & \\
\hline Chestnut oak & Quercus montana Willd. & $609(94 \%)$ & $16(3 \%)$ & $21(3 \%)$ \\
\hline Dogwood & Cornus florida L. & $723(90 \%)$ & $36(5 \%)$ & $49(6 \%)$ \\
\hline Elm & Ulmus L. & $249(90 \%)$ & $8(2 \%)$ & $21(8 \%)$ \\
\hline Hickory & Carya Nutt. & $1844(87 \%)$ & $45(6 \%)$ & $238(11 \%)$ \\
\hline Locust & Robinia pseudoacacia L. & $257(89 \%)$ & $2(1 \%)$ & $27(9 \%)$ \\
\hline Pine & Pinus L. & $1447(95 \%)$ & $14(1 \%)$ & $50(3 \%)$ \\
\hline Post oak & Quercus stellata Wangenh. & $856(92 \%)$ & $12(1 \%)$ & $57(6 \%)$ \\
\hline Red maple & Acer rubrum L. & $617(89 \%)$ & $41(6 \%)$ & $33(5 \%)$ \\
\hline Red oak & Quercus rubra L. & $1474(95 \%)$ & $20(1 \%)$ & $64(4 \%)$ \\
\hline Scarlet oak & Quercus coccinea Muenchh & $1195(94 \%)$ & $22(2 \%)$ & $43(3 \%)$ \\
\hline Sourwood & Oxydendrum arboretum (L)DC & $216(93 \%)$ & $5(2 \%)$ & $12(5 \%)$ \\
\hline Sugar maple & Acer saccharum Marshall. & $943(95 \%)$ & $17(2 \%)$ & $27(3 \%)$ \\
\hline Sycamore & Platanus occidentalis L. & $360(94 \%)$ & $24(6 \%)$ & $1(0.3 \%)$ \\
\hline Yellow poplar & Liriodendron tulipifera L. & $1207(94 \%)$ & $43(3 \%)$ & $21(2 \%)$ \\
\hline White oak & Quercus alba L. & $8472(87 \%)$ & $182(2 \%)$ & $1047(11 \%)$ \\
\hline
\end{tabular}


7 Table 3. Witness trees used in land surveys in 13 counties between 1734 and 1830 . Witness

8 trees that were from sprout origin were described in the survey notes as: bunch, bush, cluster,

9 double, forked, grub, three forked, three pronged, triple, twin, shrub, two from one root, three

10 from one root, four from one root, or a bunch growing from one root. The numbers in

11 parentheses are percentage of trees in each category by physiographic province.

\begin{tabular}{lcccc}
\hline \multicolumn{1}{c}{$\begin{array}{l}\text { Physiographic } \\
\text { Province }\end{array}$} & Single-stem trees & $\begin{array}{c}\text { Sprout-origin } \\
\text { trees }\end{array}$ & Saplings \\
\hline Piedmont & $7493(95.4 \%)$ & $113(1.4 \%)$ & $222(2.8 \%)$ & $23(0.3 \%)$ \\
Blue Ridge & $6081(86.3 \%)$ & $257(3.6 \%)$ & $684(9.7 \%)$ & $28(0.4 \%)$ \\
Ridge and Valley & $9604(87.6 \%)$ & $258(2.4 \%)$ & $1073(9.8 \%)$ & $30(0.3 \%)$ \\
Cumberland Plateau & $6738(95.9 \%)$ & $113(1.6 \%)$ & $162(2.3 \%)$ & $14(0.2 \%)$
\end{tabular}

12 
14 Table 4. Proportion of sprout-origin trees used in land survey records from 13 counties between 151734 and 1830 in the southern Appalachian Mountains. The 13 counties spanned four 16 physiographic provinces and results are shown by province.

\begin{tabular}{|c|c|c|c|c|}
\hline \multirow[b]{2}{*}{ Common name } & \multicolumn{4}{|c|}{ Percentage of sprout-origin trees by Physiographic Province } \\
\hline & Piedmont & Blue Ridge & Ridge and Valley & Cumberland Plateau \\
\hline Ash & 1.4 & 8.1 & 2.1 & 2.3 \\
\hline Basswood & 9.1 & 20.0 & 10.8 & 11.8 \\
\hline Beech & 1.6 & 4.4 & 1.8 & 0.8 \\
\hline Black gum & 1.5 & 0.7 & 0.8 & 0.0 \\
\hline Black oak & 2.2 & 2.6 & 0.9 & 0.0 \\
\hline Black walnut & 0.0 & 0.0 & 4.3 & 0.0 \\
\hline Buckeye & 0.0 & 1.8 & 3.7 & 1.7 \\
\hline Chestnut & 2.3 & 4.6 & 4.3 & 5.1 \\
\hline Chestnut oak & 0.8 & 4.2 & 1.8 & 7.3 \\
\hline Dogwood & 1.2 & 16.3 & 4.1 & 1.2 \\
\hline Elm & 0.0 & 0.0 & 5.4 & 0.9 \\
\hline Hickory & 2.3 & 2.8 & 2.4 & 0.3 \\
\hline Locust & 0.0 & 0.9 & 0.8 & 0.0 \\
\hline Pine & 0.3 & 2.0 & 1.0 & 1.4 \\
\hline Post oak & 1.9 & 0.0 & 0.0 & 0.0 \\
\hline Red maple & 0.8 & 19.2 & 3.2 & 3.6 \\
\hline Red oak & 0.8 & 2.4 & 1.0 & 2.5 \\
\hline Scarlet oak & 0.8 & 2.4 & 1.0 & 3.1 \\
\hline Sourwood & 1.1 & 0.0 & 3.5 & 3.1 \\
\hline Sugar maple & 0.0 & 1.5 & 3.6 & 0.7 \\
\hline Sycamore & 0.0 & 4.3 & 11.2 & 4.6 \\
\hline Yellow poplar & 1.7 & 4.5 & 1.6 & 2.3 \\
\hline White oak & 1.4 & 3.0 & 1.6 & 1.1 \\
\hline
\end{tabular}


18 Figure Caption:

19

20 Figure 1. The historical land survey data were gathered from 13 counties that spanned four

21 physiographic provinces in the southern Appalachian Mountains. 


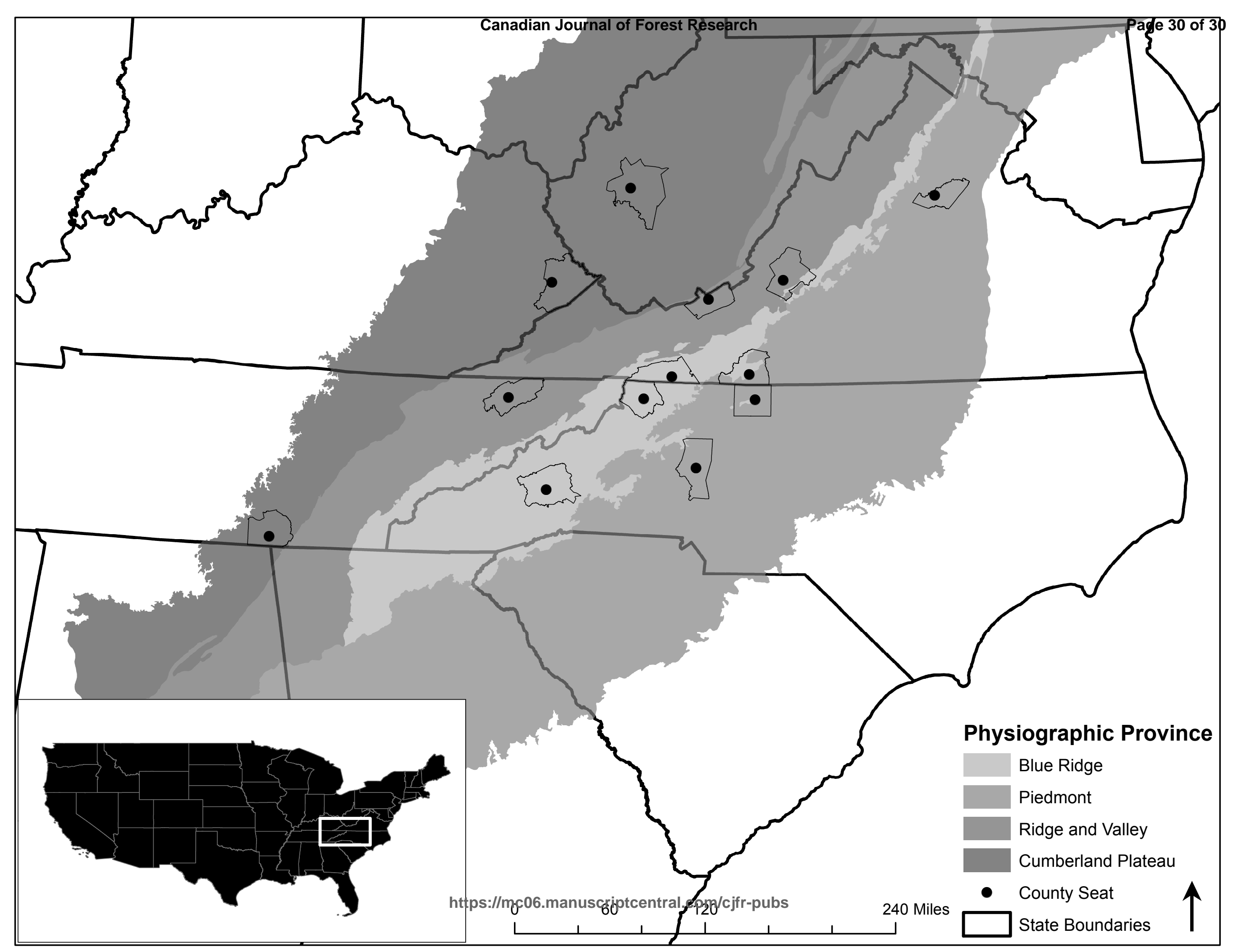

